logie," the first edition of which appeared in 1839 . Other works of like character by the same prolific author are: "Ueber den innern Bau der Gebirge" (185I), and "Geologische Fragen" (1858). In these works Bernhard von Cotta has shown himself to belong to the school of Lyell in so far as he holds unlimited time to be necessary for the explanation of geological processes.

The way in which natural sciences generally, and geology in especial, were grasped in Cotta's large and practical mind caused him earnestly to desire that geology should be more generally known and appreciated by men of average education, and he consequently published several works which, in the best sense, may be called popular. To these belong his "Letters on von Humboldt's Cosmos" (2 vols., 1851-52), "Geological Letters from the Alps" (1850), "Geolog.cal Pictures" (1852), "Catechism of Geology" (3rd edit., I877), and last, not least, deserving mention, is his great work: "Geologie der Gegenwart" (the present state of geology), the Ist edition of which appeared in 1866 , the 5 th, partly re-written and enlarged, in I878. These works have greatly contributed to put an end to those fantastical ideas about geology which so long prevailed, even amongst welleducated classes; and by promoting a sound understanding of geological states and processes, and of their bearing on practical life, they have done much to raise natural sciences in general estimation. Cotta's work, "Deutschlands Boden," must also here be named. Not only does it contain information of great importance to agriculturists, miners, and manufacturers, but statesmen, politicians, and sociologists may benefit much from studying it. It makes it plain that geology forms the basis of geography, that the outward forms we see on the surface of the earth have for the most part been inwardly conditioned. A German critic has called this work "Epochemachend," and viewed it as a first attempt to show clearly by particular instances "the influence of geological formations on the life of man."

Cotta's "Geologie der Gegenwart" merits more notice than I can here bestow upon it. It contains fifteen chapters or separate essays on that science and important subjects therewith connected. Two of these essays: "On Geology and History," and "The Development Law of the Earth," have been published by me in English. In this work the author has shown himself to be an evolutionist and a thorough adherent of Darwin's theory of the origin of species. He was one of the firstif not the first-eminent geologist who fully accepted this theory and applied it to the organic remains in sedimentary rocks. And that which in Germany has been called "Cotta's development law" is admirable and fascinating by its simplicity.

More than once has Prof. v. Cotta been in this country. On his first visit (1836) - when he made the acquaintance of Lyell-I had the pleasure of accompanying him from Germany. He has also travelled in France, Northern Italy, Tyrol, Switzerland, Hungary, the Banet, Transylvania, and the Carpathians, and has written many articles in various periodicals on his geological observations, \&c. in those lands. The number of his monographs and fugitive essays would fill a good-sized volume. Many of his earliest excursions were undertaken in the company of his friend, the celebrated geologist, Leopold von Buch; Cotta likewise enjoyed the friendship of Alexander $\mathrm{v}$. Humboldt, with whom he often corresponded. In 1868 he was invited by the Russian Government to visit the Altai Mountains to report on their geological formation, minerals, \&c. On his return to Freiberg he wrote an account of his journey and observations, and in 1871 published a large volume "Der Altai: sein geologischer Bau und seine Erzlagerstätten."

All the writings of Cotta are remarkable for lucidity, terseness, and logical reasoning. In all the desire is apparent to discover by the inductive method that con- nection of things which-even when most difficult or impossible to perceive-we know must of necessity exist. Owing to this tendency of his mind he has been said to belong to the School of Positivists. Many of Cotta's works have been translated into other languages. His "Gesteinslehre" Mr. P. H. Lawrence has admirably given in English: "Rocks Classified and Described," \&c. Numerous German and foreign academies and learned societies have bestowed upon him honorary membership, and foreign potentates have given him decorations. As long ago as 1867 von Cotta became a Foreign Correspondent of the Geological Society of London, and within the last few months the highest honour in the gift of that Society was conferred upon him by his election as Foreign Member.

In private life, as in his scientific pursuits, Bernard v. Cotta was characterised by truthfulness and directness of purpose, whilst to these qualities were added warmth and fidelity in his aftachments, and also kind consideration for the feelings and wants of his fellows in general. Thus his memory will live not only in the love and esteem of a widow and three daughters, but will likewise be cherished by those who have enjoyed his friendship. I may add that Cotta, like nearly all men of genius, was absolutely free from pedantry; that he was sympathetic and readily interested in politics, general literature, and social life. He possessed, too, a strong sense of wit and humour, and could greatly enjoy a good joke.

R. R. NOEL

\section{A ZOOLOGICAL STATION AT SYDNEY}

SEVERAL references to the scheme for the foundation of a zoological station at Sydney having appeared in NATURE since the idea was first mooted by Dr. Miclucho Maclay, it may be of interest to our readers to learn how far the project has progressed in the meantime.

A correspondent in Sydney informs us that the Government of New South Wales have granted an allotment of land for the purpose at Watson's Bay, a small wateringplace about six miles from Sydney (with which there is communication by steamer several times daily), and close to the entrance of Port Jackson. The site is an excellent one for the purpose, having a frontage of about 125 feet to Port Jackson, with good dredging-ground within a stone's throw, and so near the open Pacific (though entirely sheltered) that pelagic organisms may be obtained abundantly with the tow-net without going many hundred yards. The New South Wales Government have also promised the sum of $300 l$. towards the expense of erecting the building, which sum will be placed in the hands of the trustees when an equal amount has been raised by private subscription. The $300 l$. must be subscribed within a year, failing which the conditional promise of Government assistance will be withdrawn. As yet the subscription list does not show a total of one-third of the required sum; a circular soliciting subscriptions has therefore been issued to such in Sydney and elsewhere as are likely to take an interest in the matter. The money having been obtained, it is intended to proceed with the building on the plan proposed by Dr. Maclay. According to this plan the building will consist of two stories, the lower occupied, in addition to a small sitting-room or vestibule, by several (most probably four) well-lighted workrooms, with dissecting- and microscope-tables, aquaria, and other necessary fittings. Each laboratory will be for the accommodation of a single worker, and will communicate by a separate stairway with a bed-room on the upper storey. Those working in the station will, by this arrangement, be able to live quite independently of one another, and to work without disturbance or interruption. In the upper storey there will also be a large common room or library communicating by a stair with the vestibule. A photographic room will be built in the rear, and a boat- 
house with boat, dredges, and other collecting gear will be added. The whole will be so arranged that additional accommodation may be added when found desirable.

We need not point out the importance of the station proposed to be erected in Sydney. It is expected that most of those who will make use of the station will come from England, and therefore it will be only fair that English biologists should help our Sydney friends to complete the 300 . required for the station. There is some fear that they may not be able to raise the whole sum in the colony, and we would therefore strongly urge upon those of our readers interested in the enterprise to lend a helping hand. Dr. J. C. Cox, Hunter Street, Sydney, acts as treasurer, and Mr. George Leslie, assistant to Sir Wyville Thomson, University, Edinburgh, has been asked to become treasurer for any subscriptions that may be raised at home.

Baron Maclay, we may state, is at present engaged in an excursion in Polynesia, and will return to Sydney about the end of the present year.

\section{THE RESIGNATION OF DR. ANDREWS}

$W^{E}$ learn with great regret that Dr. Andrews has W resigned the post he has so long held as vicepresident of Queen's College, Belfast, and Professor of Chemistry. Dr. Andrews had been urged by his brother professors to allow himself to be proposed for the first vacancy in the presidency of the College, but his sense of duty urged him to give a peremptory refusal.

With reference to Dr. Andrews's work both as a professor and as a scientific worker, we quote from an excellent article in the Northern Whig of the I 8 th inst. :-

"Before the formation of the Queen's University he had been Professor of Chemistry in the medical school of the Belfast Institution, and from this post he was transferred to a similar chair in Queen's College, while at the same time he was appointed its first vice-president. "The importance of this latter office may be gathered from the fact that to a joint board, consisting of the presidents and vice-presidents of Belfast, Cork, and Galway, was remitted the arduous task of framing statutes and ordinances for the internal management of the colleges, and on this board there was certainly no stronger man than Dr. Andrews. The Queen's Colleges were launched upon the country as a great educational experiment. Founded upon the principle of united secular and separate religious instruction, they had to contend all through their career against opposition of the bitterest and most unscrupulous character. The men, therefore, who actually worked the vessel through its early dangers have deserved well of their country in no small degree, and in the front rank of these stands Dr. Andrews. And not merely was he a practical worker in the cause of united education; he has besides given to the world some of the most effective expositions of its principles. His address on the subject, delivered in 1867 to the Social Science Congress in Belfast, is one of the classics of the question, and it is not too much to say that its influence was powerfully felt in moulding opinion in England in preparation for the Liberal educational policy of 1870 . Nor was he a less well-recognised authority in regard to the general question of university education. His little work entitled 'Studium Generale,' elicited, if we mistake not, by the supplemental charter proposals, contains a most fresh and vigorous enunciation of the most enlightened views upon higher education. As a teacher of science, Dr. Andrews has been most successful. His mastery of the subject found expression in exposition of the clearest and most lucid character, while his faculty of popular experimenting was of the most delicately accurate and attractive character. $\mathrm{He}$ had a peculiar power of gathering about him the élite of the best men of the year; wherever there was a man endowed with somewhat of the true scientific spirit, he was sure to gravitate towards the laboratory; and it is an interesting fact that the great majority of Dr. Andrews's most trusted laboratory students have turned out successful men in after life.

“But, however eminent have been Dr. Andrews's services in the directions already alluded to, it is as an original scientific investigator that he has gained his principal title to an immortal place in the annals of fame. Dr. Andrews belongs to the first rank of that remarkable body of professed chemists whose researches have been more of a physical than of a chemical nature. The names of Faraday, Graham, and Regnault, at once suggest themselves in this connection; and we are quite justified in saying that in insight, accuracy, and originality, as well as in the intrinsic value of their results, Dr. Andrews's investigations will bear comparison with the very best work of these great men. We cannot here attempt to give more than a very brief notice of the results of some of the more important of Dr. Andrews's papers. The complete list will be found in that invaluable work "The Royal Society Catalogue of Scientific Papers," to which all men of science are under the deepest obligations. The most important of his earlier investigations is a brilliant series of determinations of the heat of combination of different classes of substances. Considering the difficulties of this inquiry, as shown by the preposterous results which have sometimes been given even by able experimenters, the simplicity of Dr. Andrews's methods and the recognised accuracy of his results form a striking tribute to his care and skill. The results are not only of high theoretical value as regards the constitution of matter, but also of great importance for practical determinations of the electromotive force of various voltaic combinations. Next we have his grand researches on ozone, a remarkable body first distinctly recognised by Schönbein, whose nature was long a puzzle to chemists. It was reserved for Dr. Andrews to show (I) that ozone, from whatever source derived, is one and the same body; (2) that it is an allotropic form of oxygen. Before he cleared up these points it was generally supposed by chemists that there were different kinds of ozone, and that one of them, prepared by electrolysis, was a teroxide of hydrogen. In a second research Dr. Andrews traced the volumetric changes which occur in the formation of ozone from pure oxygen by the electric discharge-where it has been long known under the name of 'the smell of lightning'-and gave a number of similar and very remarkable volumetric changes observed in other gases, simple as well as compound, produced under the same experimental conditions. He showed that the chemical activity of chlorine could be greatly increased, just as that of oxogen was, by electric discharges. This question has again only very recently been reopened by a Continental chemist, who maintains that chlorine is not an element, but a compound body. The most recent of Dr. Andrews's grand contributions to science is his classical research into the 'Continuity of the Liquid and Gaseous States of Matter.' By means of a very simple but exquisite apparatus (prepared for him under his own directions by our very skilful townsman, Mr. Cumine), be showed that it was possible to convert a gas such as carbonic acid into a liquid, or the liquid into the gas, without any discontinwity whatever. In fact, a spectator may watch the body throughout the process, assure himself that it is gas at starting, and that it is liquid at last, and yet not be able to state when the change took place. From the scientific point of view, this phenomenon is best described by the use of Dr. Andrews's discovery of the 'critical point,' as it is called. For every gas or vapour there is a special temperature called its critical point, which is such that only when the temperature of the gas or vapour is under that point can it exist in presence of the liquid; so that the portion liquefied can be distinguished from the 